DOI https://doi.org/10.30525/978-9934-26-039-1-5

\title{
ФЕМІНІТИВИ В МОВІ МЕДИЦИНИ
}

\author{
Лещенко Т. О. \\ кандидат філологічних наук, доцент, \\ завідувачка кафедри українознавства та гуманітарної підготовки \\ Української медичної стоматологічної академії
}

Жовнір М. М.

кандидат філологічних наук, викладач кафедри украӥнознавства та гуманітарної підготовки Української медичної стоматологічної академії м. Полтава, Україна

Адекватно й оперативно реагуючи на виклики часу, сучасна українська мовознавча наука стрімко й невпинно розвивається, розширюючи межі традиційного категорійно-термінологічного апарату. Не оминула ця тенденція й гендерну лінгвістику - відносно новий мовознавчий напрям, зосереджений на вивченні гендерних аспектів мовних систем різних галузей із залученням відповідного поняттєвого апарату.

Оскільки відносини й соціальні практики, норми поведінки i взаємодії, за допомогою яких диференціюють ста́ті, виформовуються в конкретному мінливому соціальному контексті, проблему мовної репрезентації образів чоловіків і жінок у науковому світі вважають актуальною, про що свідчить низка праць (О. Авраменко, А. Архангельська, М. Брус, 3. Валюх, М. Вербовська, І. Ковалик, О. Малахова, А. Нелюба, О. Синчак, В. Слінчук, О. Пономарев, С. Семенюк, О. Соколинська, О. Чуєшкова, Г. Ярманова та ін.).

Попри те, що в українській лінгвістиці перші студії гострих проблем гендеру було започатковано ще наприкінці 80 -х років, питання, дотичні до лінгвістичної гендерології, досі залишаються одними 3 пріоритетних напрямів досліджень вітчизняних і західних мовознавців.

У полі нашого зору - кореляти до чоловічих іменувань за професією в галузі медицини. Мета праці - проаналізувати особливості творення й функціонування в медичному дискурсі морфологічних одиниць на позначення професій, маркірованих граматичним жіночим родом. До аналізу залучено контент мережі Інтернет як віртуальне поле втілення актуальних мовних тенденцій і змін у лінгвальній системі медицини. 
Мова зазвичай негайно реагує на будь-які позамовні зрушення й оновлення, зміни в ній динамічні й невпинні: «Позамовна сучасність безупинно диктує вектори внутрішньолінгвального розвитку. У мові відбиваються надважливі історико-культурні й соціально-історичні події, особливості людського мовного чуття, багатовіковий досвід» [2].

Фіксує мова й активізацію уваги до словотвірної підсистеми фемінітивів, на позначення яких уживають різні терміни й номінації: категорія «жіночість», найменування жінок (О. Земська), «назви істот жіночого роду», «назви жіночого роду» (І. Ковалик), «фемінітиви» (А. Архангельська, 3. Валюх), «назви осіб жіночої статі», «назви жінок», «фемінний новотвір» (А. Архангельська) тощо.

У цій праці ми вживатимемо найбільш узвичаєний натепер варіант фемінітиви. Їх традиційно тлумачимо словами, які позначають альтернативні або парні поняттям чоловічого роду номінації жіночого. Передовсім ідеться про назви професій (депутатка, викладачка, лікарка, міністерка), видів діяльності (діячка, меценатка, письменниия, піарниия, спостерігачка), номінації за соціальним статусом, релігійними / світоглядними переконаннями, поглядами (графиня, хіромантка, ідеалістка, гуманістка), рисами характеру (розумниия, пліткарка, сміливиця, скандалістка) тощо.

Насамперед зазначимо, що в сучасному медичному дискурсі з часу прийняття нового українського правопису стали широко варіюватися й тезауруси дискурсивних моделей. В активний обіг стрімко входять фемінітиви на позначення назв жіночих професій у медичній сфері. Їхнє вживання поки що лишається поза нормою, оскільки вони ще й досі не кодифіковані в словниковому реєстрі. Чи стануть фемінітиви в мові медицини нормою, будуть вирішувати не мовознавці, а суспільство, яке повсякчас оперує словами, що увиразнюють гендерну асиметрію в професійній сфері: «Медикиня наголосила, що робота з контактними особами вкрай важлива під час будь-якої епідемї̈»; «У Рівному вибухнув гучний скандал через відео з дитячою лікаркою-стоматологинею, на якому вона знущалася зі своїх пацієнтів»; «Лікарка-анестезіологиня Чернівецької міської лікарні вдруге отримала позитивний результат тесту на коронавірус» тощо.

Прикметно, що способи творення й варіативність фемінітивів, які побутують в усному й писемному дискурсах, не завжди вмотивовані вітчизняною словотвірною нормою. Традиційно в українській мові для творення іменників - назв осіб жіночої статі послуговуються 13 суфіксами [1]. Найпродуктивнішим вважають суфікс -к-, оскільки він поєднується з різними типами основ: лікар - лікарка, фельдщер - 
фельдшерка, лаборант - лаборантка. Суфікс -иц-(я) сполучають із основами на -ник: помічник - помічниця, керівник - керівничя очільник - очільниия. Суфікс -ин-(я) приєднують насамперед до основ на -ець: фахівець - фахівчиня. Останнім часом спостерігаємо тенденцію додавати суфікс

$-и н-$ до основ на -ець, а також до основ на приголосний, які традиційно вважали такими, від яких не можна утворити фемінітив: гематолог - гематологиня, кардіолог - кардіологиня, онколог онкологиня.

Залучивши до аналізу численні дописи в соціальних мережах і в різноманітних інтернетвиданнях, робимо висновок про помітне почастішання випадків уживання номінацій професій, які диференціюють статі: «Фельдшерка однієї з підстанцій швидкої допомоги на умовах анонімності погодилася розповісти Суспільному, як зараз праџюють бригади»; «Терапевтка Тетяна Аникєєва розповіла про густу кров при COVID-19»; "Що робити під час полінозу, розповіла алергологиня Волинської обласної клінічної лікарні Оксана Критюк»; «Кардіологиня розповіла, що COVID-19 робить із нашими сериями» тощо.

Окремо зауважимо про відсутність єдиного узуального стандарту послуговування словотвірними формантами для творення фемінітивів, варіативність новотворів, хитання в межах норми як звичне явище в мовній практиці на етапах упровадження змін до кодифікованого літературного стандарту. До прикладу, паралельно вживаються лексеми хірургка - хірургиня, педіатерка - педіатриня, ортопедка - ортопединя, терапевтка - тератевтеса, ревматологка - ревматологиня тощо: «Також хірургиня розповіла про процедуру вакцинації»; "Що ж це виходить, людоньки, це та тендітна дитяча хірургка вбила Шеремета?»; «Педіатриня радить батькам, які мають одну дитину, запобігти появі в неї надмірної ваги, звертаючи особливу увагу на створення "здорових $і$ активних домашніх умов»; "Наша педіатерка рекомендувала з народження спілкуватися з дитиною тією мовою, яка для нас самих є рідною».

Функціонують прикладкові словосполучення зі словом лікар / лікарка й характеристикою особи за професією 3 відповідним суфіксом зі значенням фемінності: "Я вирішила перекваліфікуватися на лікаркуендоскопістку»; «Лікарка-гастроентерологиня, терапевтка Свгенія Белінська розвінчує найпотиреніші міфи в проєкті « $E$ здорове питання!»; "Чернівечька лікарка-патологоанатом про «нежіночу» професію, роботу в умовах епідемії, зарплату, хобі та сім'ю»; «Цим собі тільки шкодите», - застерігає лікарка-дієтолог». 
Натрапляємо й на випадки штучного надуживання фемінітивами й нагромадження невмотивованих новотворів від слів-назв професій - на позначення жіночої статі: «Професійні медсестри, доглядачі допомагають медсестрам надавати базовий догляд за паиієнтами й моніторинг»; "Але штора хитнулася, $і$ лище медсестрищі замаячіло над народним иілителем»; «Цікаво, щзо в кліпі активно використовуються фемінітиви: медсестриня, прем'срка тощо, що трапляється не так уже й часто».

Отож, у новітньому українському словотворі активно послуговуються формантами для створення номінацій, які позначають гендерну асиметрію в професійній сфері. Адекватне це твердження й для медичної галузі, що вповні відображено на ії лінгвістичному рівні. Спостереження показало, що різні суфікси можуть утворювати варіанти фемінітивів із однаковим лексичним значенням. Трапляються випадки ненормативного вживання суфіксів зі значенням фемінності, їхня варіативність.

Перспективи кодифікації фемінітивів прогнозувати зарано: у науковому світі й серед носіїв мови вирізняються ті, для кого впровадження омовлених норм - це надважливе завдання, а офіційне визнання фемінітивних форм - це крок до усвідомлення українцями значення гендерної толерантності. Натомість, надуживання штучними, часто незвичними, створеними на грунті давніх українських правописних традицій формами й новотворами на позначення назв осіб за статтю ставить під сумнів безперешкодний розвиток цього словесного сектора.

Подальше дослідження функціонування фемінітивів у медичному дискурсі може відбуватися в напрямі вивчення нормативності їх творення й уніфікації вживання.

\section{Література:}

1. Брус М. Фемінітиви української мови в переплетенні давніх і сучасних тенденцій. Вісник Лвів. ун-ту. Серія Філологія. 2009. Вип. 46. Ч. 1. C. 61-69.

2. Лещенко Т. О., Бондар Н. В., Жовнір М. М. Український правопис: новації та варіації : наочно-навчальний посібник. Полтава. УMCA, 2020. $40 \mathrm{c}$. 